
小特集 スマートフォンから 見る ICT 技術

\section{私の技術者歴 遠藤信博}

開発物語：絵文字はどのようにして生まれ, 世界に広がっていったのか? 街plus 探訪：フィンランド, オウル

技術と制度のおはなし：情報通信分野の研究活動を応援する競争的資金 制度について

子どもに教えたい通信のしくみ：個人の情報とコンテンツを守る仕組み

..他，御期待下さい

\title{
Editors Note
}

今回の小特集は「知られざる業務無線」でした. いかがでし たでしょうか. 編集を担当することで, 業務無線の技術が, 防災，交通，そのほか，多くの社会インフラを支えている， ということを再認識できました。

(Y.A.)

今回は開発物語を担当させて頂きました. 快く御執筆をお引き 受け頂くとともに, 将来を見越した技術実現に向けた大型開発 における当時の御苦労等, 貴重なお話を伺う機会にも恵まれま した. 大変感謝申し上げます. ありがとうございました.

(T.M.)

防災・減災を支える情報通信技術に関する記事を担当しまし た．災害への対策は技術の進歩だけでなくそれを利用する側 の正しい知識も重要であるという認識が少しでも多くの方々 に伝わることを願っています.

(M.S.)

最近, 一眼レフカメラを購入し, 親バカのように子供の写 真を撮っています. カメラには無線LANが付いているので, そのままスマホへ転送すれば簡単に閲覧できて便利．次の ボーナスは無線機能付きのプリンタを狙います.

編集委員 3 年目となりました．本マガジンを通信の観点 を大事にしつつも通信の枠にとらわれず，気軽に読んで 頂ける雑誌にしていけたらと思っています．今後とも御 愛読頂けますようよろしくお願い申し上げます.

(R.K.)

今回の「若者よ，世界に出よう!」コーナーは留学生で なく，既に日本で職に就かれている方に執筆をお願いし ました．国を跨いだキャリア形成として参考になると思 います．是非御一読下さい.

(K.I.)

季刊のため企画から締切など相当な期間が経過し，今回も皆 様に助けて頂きながら，編集後記にまで至ったように思いま す。おかげさまで，良い特集・すばらしい記事ができたよう に思います。こうした一つ一つの地道な作業を紡いで，マガ ジン誌がまた一つ出来上がってよかったです.

(K.K.)
私たちの生活を支える鉄道や航空用，安全を守る防災用 の業務用無線システムには，それぞれに特有の用途があ り，興味深い内容となっています．9月1日は防災の日 です．時節に合った特集に参加できてよかったです．

(K.H.)

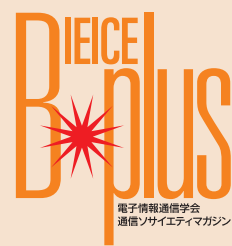

2017 年秋号 (第 42 号) 2017 年 9 月 1 日発行

\section{EDITORIAL COMMITTEE} 編集委員長 岩井誠人

編集副委員長 羽多野裕之 吉村直子

$$
\text { 編集委員 }
$$

$\begin{array}{llll}\text { 明星慶洋 } & \text { 有馬卓司 } & \text { 石橋圭介 } & \text { 井上和弘 } \\ \text { 鎌倉浩嗣 } & \text { 久保亮吾 } & \text { 後藤 薫 } & \text { 小林亜樹 } \\ \text { 齋藤康弘 } & \text { 笹部昌弘 } & \text { 鈴木健治 } & \text { 田久 修 } \\ \text { 谷 重紀 } & \text { 登内敏夫 } & \text { 橋本尚久 } & \text { 畑本浩伸 } \\ \text { 平野拓一 } & \text { 福元徳広 } & \text { 古川智章 } & \text { 真鍋哲也 } \\ \text { 山田 曉 } & \text { 山中仁昭 } & \text { 湯田泰明 } & \end{array}$

本誌の愛称は「B-plus」, 正式名称は「通信ソサイエティマガジン」, 「IEICE Communications Society Magazine」です。

本誌揭載論文を文献引用する際は，邦文略称「信学通誌」，英文略称 IEICE Commun. Mag.」を用いて下さい.

\section{通信ソサイエティマガジン B-plus へのお問い合わせ}

$\square$ ご意見，で要望：b-plus@ieice.org

ロホームページ \https://www.ieice.org/ cs-edit/magazine/index.htm

$\square$ B-plus 冊子体購入のお申込みはこちら https://www.ieice.org/ cs-edit/magazine/order_y.html.utf8

\section{複写される方へ}

本会は，本誌掲載著作物の複写に関する権利を一般社団法人学術著作権協会に委託してお ります. 本誌に掲載された著作物の複写を御希望の方は, (社) 学術著作権協会より許諾を受 けて下さい、ただし、企業等法人による社内利用目的の複写については，当該企業等法人か 公益社団法人日本複製権センター（(社）学術著作権協会が社内利用目的複写に関する権利を 再委託している団体）と包括複写許諾契約を締結している場合にあっては，その必要はござ いません。（社外頒布目的の複写については，許諾が必要です）

権利委託先 : 一般社団法人学術著作権協会

T 107-0052 東京都港区赤坂 9-6-41 乃木坂ビル 3F

Fax : 03-3475-5619 E-mail : info@jaacc.jp

複写以外の許諾（著作物の引用，転載，翻訳等）に関しては，（社）学術著作権協会に委託 致しておりません，直接，下記へお問い合わせ下さい，

問合せ先 一般社団法人 電子情報通信学会

干 105-0011 東京都港区芝公園 3-5-8 機械振興会館内

Tel : 03-3433-6691 Fax : 03-3433-6659

発行人 /蔉毛正洋

発行所/一般社団法人 電子情報通信学会 通信ソサイエティ 干 105-0011 東京都港区芝公園 3-5-8 機械振興会館 Tel : 03-3433-6691 (代表) 振替 : 00120-0-35300

制 作 /三美印刷（株） 東京都荒川区西日暮里 5-9-8

(C) Copyright 2017 IEICE. All rights reserved. 